\title{
Perancangan Aplikasi Surat Masuk dan Keluar pada PT. Angkasa Pura 1 Semarang
}

\author{
Endang Sugiharti ${ }^{1}$ \& Sulis Eli Triliani ${ }^{2}$ \\ ${ }^{1}$ Jurusan Ilmu Komputer, FMIPA, Universitas Negeri Semarang \\ ${ }^{2}$ Jurusan Matematika, FMIPA, Universitas Negeri Semarang \\ Email: endanghs02@yahoo.com
}

\begin{abstract}
Abstrak. Salah satu permasalahan dalam pengelolaan surat di PT. Angkasa Pura 1 terutama dalam pencatatan surat masih menggunakan pencataan dalam buku agenda dan menggunakan Microsoft Excel sebagai catatan record transaksi surat. Dengan banyaknya jumlah surat yang dibuat maka pencarian akan tidak menjadi efisien. Salah satu upaya untuk mengatasi hal tersebut adalah dengan membuat sistem aplikasi surat masuk dan keluar dengan menggunakan Visual Basic 6.0, MySQL sebagai databasenya dan crystal report untuk pembuatan laporannya. Data yang digunakan dalam pembuatan sistem aplikasi ini adalah data surat masuk dan data surat keluar PT. Angkasa Pura 1 (Persero) kantor cabang Bandar Udara Internasional Ahmad Yani Semarang tahun 2013-2014.

Hasil dari perancangan sistem aplikasi ini adalah sistem aplikasi penginputan data surat masuk dan surat keluar, update data surat masuk dan keluar, pencarian data surat masuk dan keluar, pembuatan laporan data surat masuk dan keluar. Peneliti menyarankan bahwa sistem aplikasi ini dapat digunakan pada PT. Angkasa Pura 1 (Persero) kantor cabang Bandar Udara Internasional Ahmad Yani Semarang. Apabila sistem aplikasi tersebut ingin dikembangkan, bisa dikembangkan menjadi client server.
\end{abstract}

Kata kunci: Surat; Visual Basic 6.0; MySQL.

\section{PENDAHULUAN}

Surat adalah alat komunikasi tertulis yang berasal dari satu pihak dan ditujukan kepada pihak lain untuk menyampaikan warta [1]. Surat masuk/ keluar merupakan hal yang tidak dapat dihindari dalam suatu perusahaan dan memegang peranan penting dalam proses administrasi. Surat masuk/ keluar merupakan rekaman kegiatan ataupun peristiwa dalam suatu instasi dan harus disimpan dalam jangka waktu tertentu untuk kebutuhan tertentu. Manajemen surat masuk/ keluar dibutuhkan untuk mengatur jalannya suatu prosedur dalam suatu perusahaan.

Surat masuk adalah semua jenis surat yang diterima dari instasi lain maupun dari perorangan, baik yang diterima melalui pos (kantor pos) maupun yang 
diterima dari kurir (pengiriman surat) dengan mempergunakan buku pengiriman. Surat keluar ialah surat yang lengkap (bertanggal, bernomor, berstempel dan telah ditandatangani oleh pejabat yang berwenang) yang dibuat oleh instasi atau lembaga lain [6].

Prosedur pengelolaan surat masuk yang baik meliputi; pengelompokkan surat, membuka surat, pemeriksaan surat, pencatatan surat dan pendistribusian surat, sedangkan untuk surat keluar meliputi; pembuatan konsep, persetujuan konsep, pengetikan surat, pemberian nomor, penyusunan surat, pengiriman surat. Angkasa pura 1 merupakan suatu perusahaan yang mempunyai visi yaitu menjadi salah satu dari sepuluh perusahaan pengelolaan pengelola bandar udara terbaik. Prosedur dalam pengelolaan surat terutama pencatatan surat pada PT. Angkasa Pura 1 (Persero) kantor Cabang Bandar Udara Internasional Ahmad Yani Semarang saat ini masih menggunakan pencatatan dalam buku agenda dan menggunakan Microsoft excel sebagai catatan record transaksi surat. Aplikasi ini memang mudah dipahami oleh pengguna karena memiliki interface yang mudah [5].

Penggunaan Software Spreadsheet ini efektif untuk pengolah data yang simpel. Hanya saja software ini tidak mampu mengelola dengan baik untuk data yang terus bertambah [5]. Selain itu, software ini tidak efisien untuk mengelola data parsial terutama dalam hal kapasitas penyimpanan dan performance yang dihasilkan. Software ini juga tidak bisa melakukan validasi berkaitan dengan tipe data pada setiap cell yang ada. Dengan sistem seperti ini, maka sangat mungkin terjadi redudansi sehingga kualitas data yang dihasilkan tidak mudah dikontrol. Hal lain yang tidak bisa dikelola dari penggunaan software ini adalah berkaitan akses kontrol pada data yang ada.

Kekurangan pada software spreadsheet ini dapat digantikan oleh MysQL. MySQL adalah sebuah perangkat lunak sistem manajemen basis data Structure Query Language (SQL) atau Database Management System (DBMS) yang multithread dan multi-user [4]. MySQL tersedia sebagai perangkat lunak gratis di bawah lisensi GNU General Public License (GPL), tetapi mereka juga menjual di bawah lisensi komersial untuk kasus-kasus di mana penggunaannya tidak cocok dengan penggunaan GPL yaitu MySQL Enterprise.

Microsoft Visual Basic adalah bahasa pemrograman yang cukup populer dan mudah untuk dipelajari, dapat membuat program dengan aplikasi GUI, atau program yang memungkinkan pengguna komputer dapat berkomunikasi mengunakan media grafik atau Gambar dengan komputer [2]. Program ini 
mudah digunakan untuk pemprograman berbasis desktop dengan mengkombinasikan MySQL.

Dalam program Visual Basic ini, dalam membuat laporan, bisa dikombinasikan dengan CR (Crystal report). Secara defacto dapat dikatakan CR adalah peranti standar untuk pembuatan laporan pada sistem operasi Windows, di mana cetakan/ template laporan yang dihasilkan dapat disertakan pada banyak bahasa pemrograman [3].

Crystal report adalah program third party (pihak ketiga, artinya di luar Microsoft dan pemakai) untuk membuat laporan pada aplikasi windows dan web. Sekarang, program crystal report diintegrasikan ke dalam Visual Basic.net sehingga menjadi bagian dari lingkungan pengembangan IDE (Integrated Development Environment) aplikasi Visual Basic.net. Hal ini terutama terlihat pada bagian crystal report designer untuk mendesain dan memodifikasi laporan. Untuk mempermudah membuat laporan disediakan fitur crystal report experts yang mirip dengan wizard pada Microsoft.

Aplikasi manajemen surat masuk/ keluar dengan kombinasi software visual basic 6.0, MySQL dan Crystal Report ini diharapkan akan memberikan keefisienan waktu dan keamanan dalam pembuatan maupun penyimpanan surat masuk/ keluar. Dalam hal ini sistem tata persuratan menjadi salah satu faktor yang berpengaruh dalam pengelolaan surat, sehingga diharapkan pengelolaan surat baik surat masuk atau surat keluar dapat dilakukan dengan lebih baik, cepat dan mudah. Perancangan aplikasi ini juga memudahkan proses komunikasi data antar bagian serta pembuatan laporan yang selalu up to date dan bisa dilihat berdasarkan laporan bulanan maupun tahunan.

\section{METODE}

Dalam perancangan aplikasi surat masuk dan keluar pada PT. Angkasa Pura 1 Semarang mempunyai beberapa tahapan diadopsi sesuai dengan siklus hidup sistem informasi [7] sebagai berikut: (1) Tahap pengambilan data awal, (2) Tahap analisis kebutuhan sistem, (3) Tahap Pembuatan desain, (4) Tahap pembuatan program. Hasil rancangan dan pembuatan program diuraikan dan dijelaskan secara deskriptif naratif.

Untuk mengecek keberhasilan dari system, dilakukan tahap pengujian. Tahap ini adalah dengan melakukan uji mengenai kesalahan-kesalahan yang ada dalam pembuatan program. Kesalahan-kesalahan dalam pengujian adalah sebagai berikut. 
1. Kesalahan Bahasa, merupakan kesalahan dalam penulisan kode program yang kurang tepat dengan kriteria dan bahasa pemrograman dari program yang digunakan.

2. Kesalahan Proses, merupakan kesalahan yang muncul ketika program dijalankan. Kesalahan ini mengakibatkan program berhenti melakukan proses sebelum seharusnya program tersebut berhenti karena program tidak menemukan objek yang dijalankan.

3. Kesalahan Logika, merupakan kesalahan yang cukup sulit ditemukan karena kesalahan ini tidak tampak jelas saat program dijalankan. Program tetap bisa berjalan dengan normal dan menampilkan hasil, akan tetapi hasil yang ditampilkan tidak sesuai dengan yang diharapkan [7].

\section{HASIL DAN PEMBAHASAN}

\subsection{Aplikasi Surat Masuk dan Surat Keluar}

Aplikasi surat masuk dan keluar berfungsi untuk mempermudah dalam pengelolaan data surat masuk dan keluar. Melalui program ini pengguna dapat melakukan input data surat masuk dan keluar, penyimpanan data, edit data, pencarian data dan membuat laporan data surat masuk dan keluar bulanan dan tahunan. Aplikasi surat masuk dan keluar memiliki beberapa menu yaitu menu file, pencarian, laporan data surat masuk dan keluar, logout, serta memiliki beberapa form antara lain form login, form input data surat masuk dan keluar, form pencarian, form input data user, form lihat data perusahaan dan form laporan.

\subsubsection{Halaman Awal}

Halaman awal dari sistem aplikasi ini adalah halaman login yang merupakan tampilan awal ketika aplikasi dijalankan. Gambar 1 menunjukkan form untuk login dan terdapat dua inputan yaitu username dan password. Pada form ini terdapat dua pilihan untuk login user dan login admin.

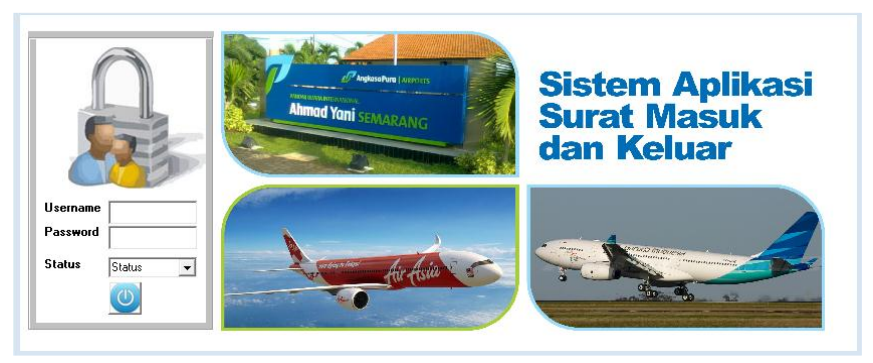

Gambar 1 Halaman awal tampilan login. 
Gambar 2 merupakan tampilan saat program dijalankan, jika dalam pengisian username atau password salah maka akan muncul peringatan. Jika dalam pengisian username dan password benar dan status admin maka akan menuju halaman admin seperti pada Gambar 3. Jika username dan password yang diisi benar dan status user maka menuju halaman user seperti pada Gambar 16.

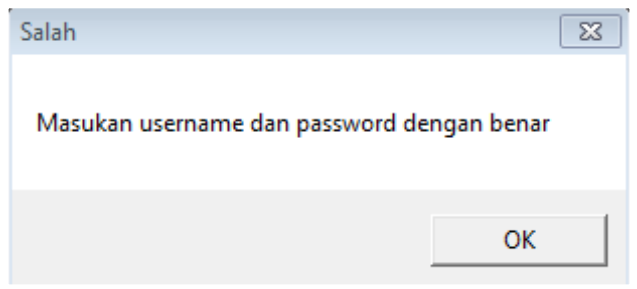

Gambar 2 Gambar kotak dialog peringatan login.

\subsubsection{Halaman Admin}

Sebelum melakukan input data surat masuk dan keluar, langkah pertama adalah admin harus masuk melalui menu login admin. Setelah masuk di halaman admin maka akan terlihat beberapa menu seperti tampak pada Gambar 3.

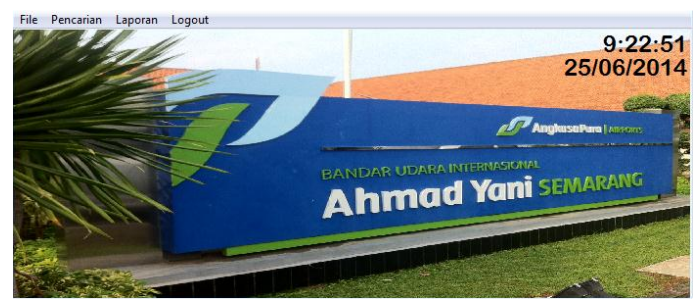

Gambar 3 Halaman admin.

Gambar 3 merupakan halaman admin di mana terdapat beberapa menu yaitu menu file, pencarian, laporan dan logout. Hal yang bisa dilakukan oleh admin yaitu input data surat masuk, input data surat keluar, input data pegawai, melihat data perusahaan, pencarian data surat masuk dan keluar, membuat laporan, serta mencetak laporan data surat masuk dan keluar secara keseluruhan atau total dan bisa bulanan/ tahunan. Menu yang terdapat dalam halaman admin adalah sebagai berikut:

1. Menu File

Menu file ini berisi form input data surat masuk dan surat keluar, input data user atau anggota dan melihat data perusahaan. Tampilan halaman menu file dapat dilihat pada Gambar 4. 


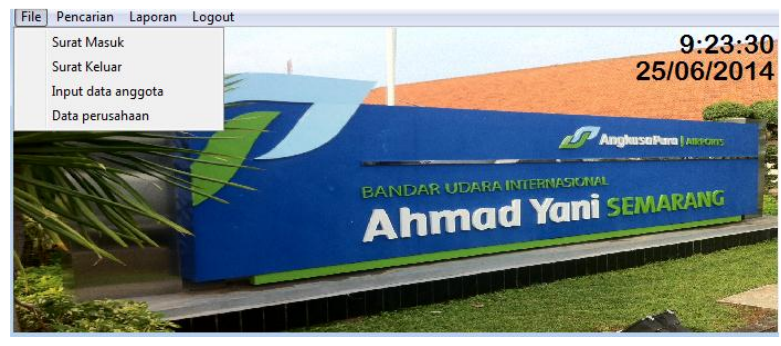

Gambar 4 Tampilan menu file.

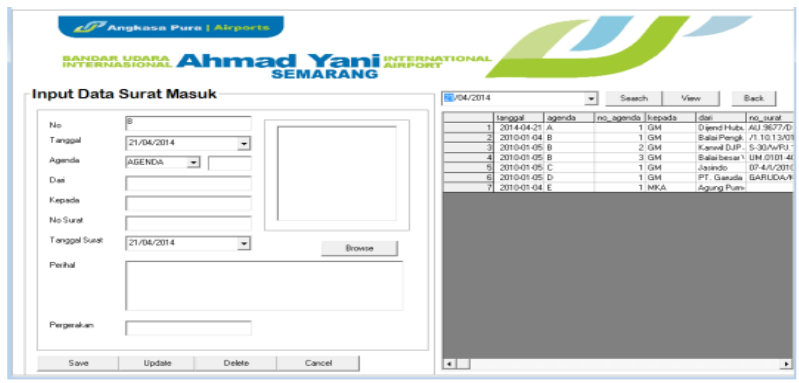

Gambar 5 Form input data surat masuk.

Gambar 5 merupakan form input data surat masuk yang terdapat dalam menu file pada halaman admin yang digunakan untuk melakukan proses penginputan data surat masuk dan data akan disimpan dalam database surat masuk. Dalam proses penginputan data surat masuk ini ada beberapa hal yang hasus diinputkan yaitu no, tanggal, jenis agenda, dari, tujuan, no surat, tanggal surat, perihal, pergerakan dan photo yang digunakan untuk menyimpan/ mendokumentasikan gambar surat hasil scanning. Pada form input data surat masuk, admin bisa melihat data surat masuk, pencarian data surat masuk berdasarkan tanggal dan bisa mengedit/ menghapus data surat masuk.

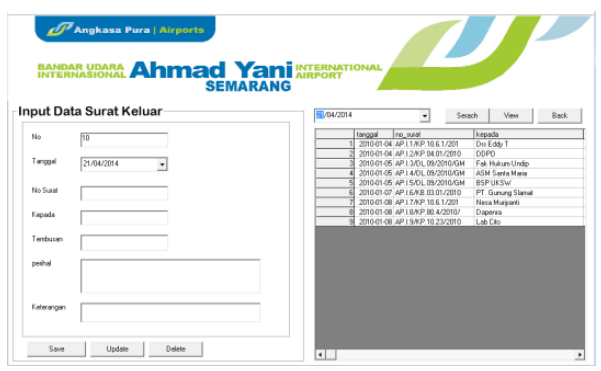

Gambar 6 Form input data surat keluar. 
Gambar 6 merupakan form input data surat keluar yang terdapat pada menu file pada halaman admin, digunakan untuk menginputkan data surat keluar yang akan disimpan dalam database surat keluar. Ada beberapa hal yang harus diinputkan dalam form surat keluar yaitu no, tanggal, no surat, tujuan, tembusan, perihal dan keterangan. Pada form ini admin bisa melihat data surat keluar, melakukan pencarian data surat keluar berdasarkan tanggal dan bisa mengedit/ menghapus data surat keluar.

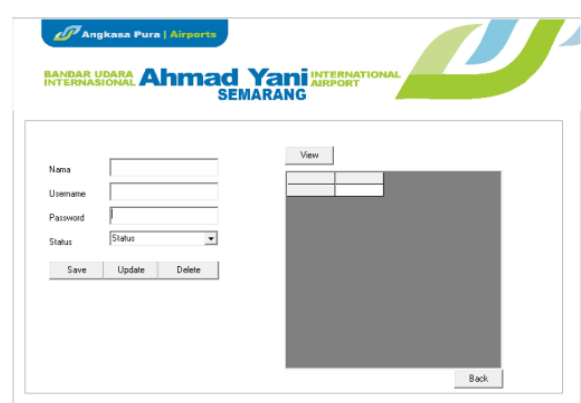

Gambar 7 Form input data user.

Gambar 7 adalah form input data user, digunakan untuk menginputkan data admin dan user. Proses penginputan data user hanya bisa dilakukan oleh admin karena hanya terdapat pada halaman admin. Admin bisa melihat data userl admin dan bisa mengedit/ menghapus data user.

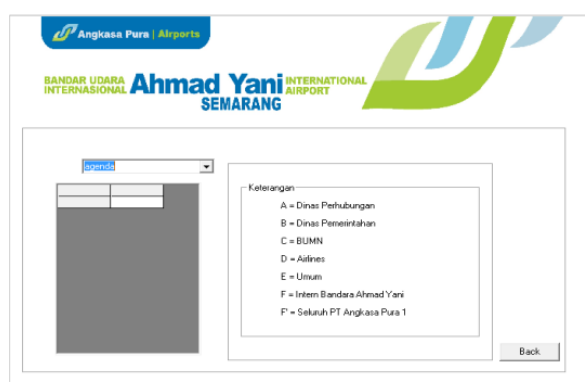

Gambar 8 Form data perusahaan.

Gambar 8 merupakan form data perusahaan yang terdapat dalam halaman admin. Form ini digunakan untuk melihat daftar perusahaan yang ada dalam database dari hasil proses inputan data surat masuk. Pada form ini terdapat keterangan jenis agenda, hal ini bisa untuk memudahkan seorang admin ketika menginputkan data surat masuk. 
1. Menu pencarian

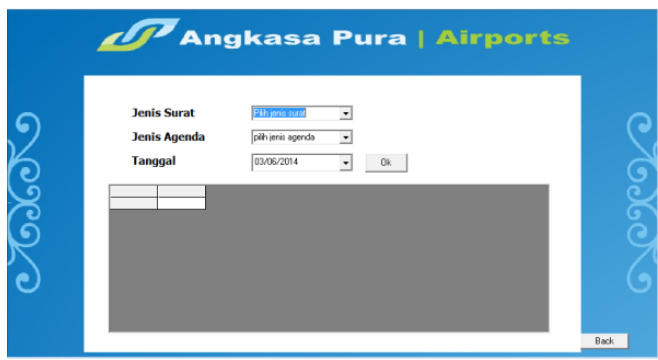

Gambar 9 Tampilan menu pencarian.

Gambar 9 merupakan menu pencarian yang terdapat pada halaman admin. Menu ini digunakan untuk melakukan proses pencarian data surat masuk/ keluar dan dapat melakukan pencarian berdasarkan jenis agenda dan berdasarkan tanggal.

2. Menu Laporan

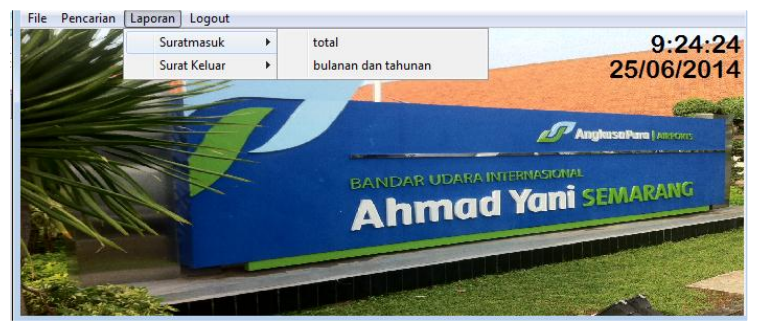

Gambar 10 Tampilan menu laporan surat masuk.

Gambar 10 merupakan tampilan menu laporan di mana terdapat beberapa menu pilihan yaitu laporan surat masuk dan surat keluar serta terdapat submenu surat masuk yaitu laporan total data surat masuk dan laporan bulanan dan tahunan data surat masuk. Contoh laporan data surat masuk dapat dilihat pada Gambar 11 . 


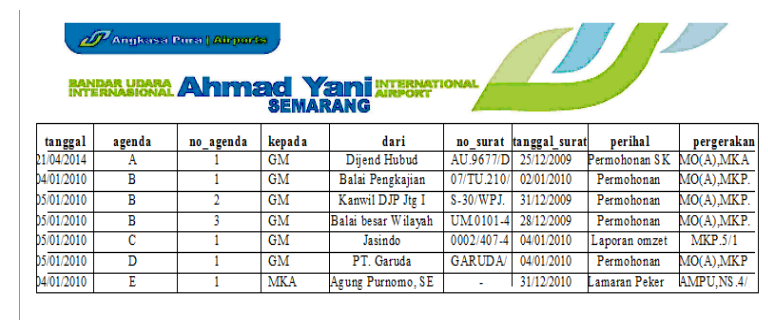

Gambar 11 Tampilan cetak laporan total data surat masuk.

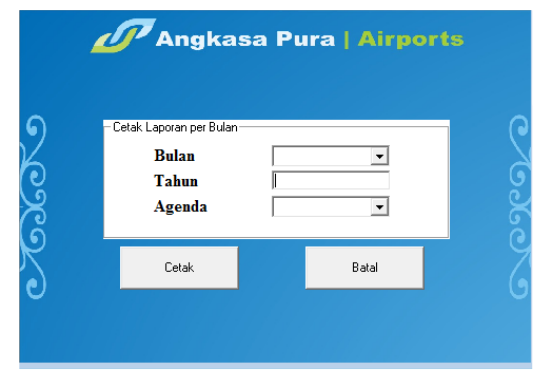

Gambar 12 Tampilan form cetak laporan data surat masuk bulanan dan tahunan.

Form cetak laporan data surat masuk yang terdapat pada Gambar 12 digunakan admin ketika akan mencetak laporan data surat masuk tiap bulan, tiap tahun dan mencetak laporan bulanan per agenda.

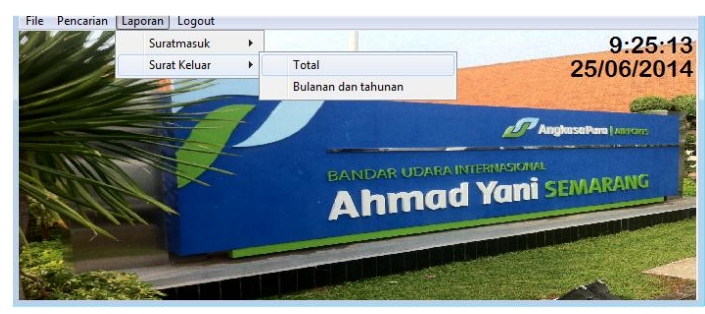

Gambar 13 Tampilan menu laporan surat keluar.

Gambar 13 merupakan tampilan menu laporan data surat keluar di mana terdapat beberapa menu pilihan yaitu laporan surat masuk dan surat keluar dan terdapat submenu surat keluar yaitu laporan total data surat keluar dan laporan data surat keluar bulanan dan tahunan. Contoh laporan data surat keluar terdapat pada Gambar 14. 


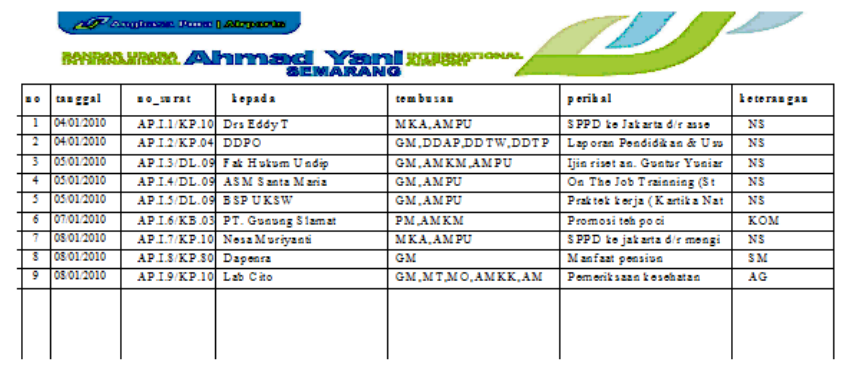

Gambar 14 Tampilan laporan total data surat keluar.

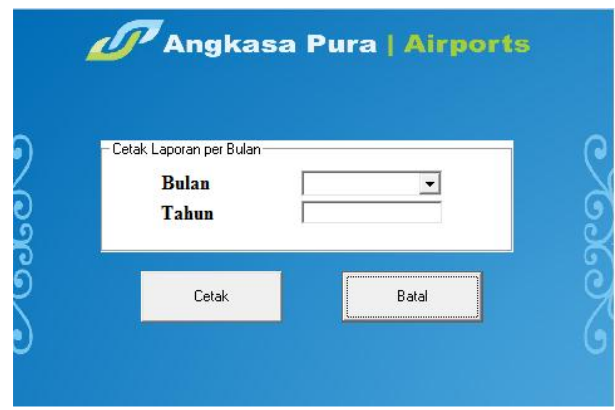

Gambar 15 Form laporan data surat keluar bulanan dan tahunan.

Form cetak laporan data surat keluar yang terdapat pada Gambar 15 digunakan admin ketika akan mencetak laporan data surat keluar bulanan dan tahunan. Dengan memilih bulan dan mengisi tahun maka akan mencetak data surat keluar sesuai dengan pengisian bulan dan tahun pada form.

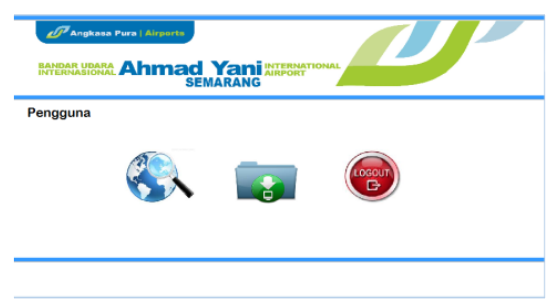

Gambar 16 Halaman user.

Halaman user yang terdapat pada Gambar 16 akan muncul setelah seorang user login pada halaman login. Pada halaman user terdapat beberapa menu yaitu menu pencarian, cetak laporan dan logout. User bisa melihat data surat masuk 
dan surat keluar, mencetak laporan dan melakukan proses pencarian data surat masuk dan keluar.

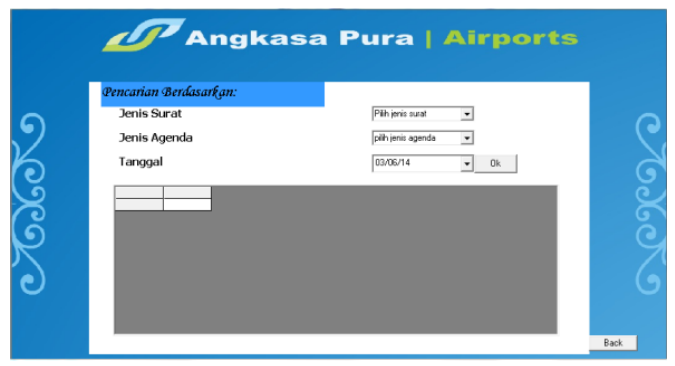

Gambar 17 Form pencarian halaman user.

Seperti pada halaman admin yang bisa dilihat pada Gambar 17, form pencarian di halaman user juga terdapat pilihan untuk melakukan proses pencarian data surat masuk/ keluar dan melakukan pencarian data surat masuk/ keluar berdasarkan tanggal dan agenda.

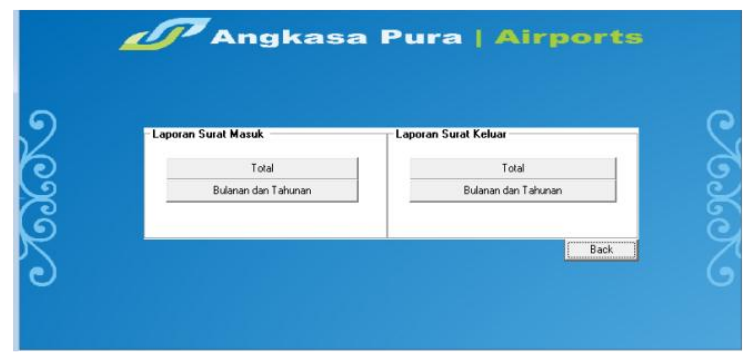

Gambar 18 Form laporan halaman user

Pada form laporan yang terdapat pada halaman user yaitu Gambar 18 digunakan untuk user jika akan mencetak laporan data surat masuk dan keluar. Menu cetak laporannya juga sama seperti menu yang terdapat pada halaman admin yaitu laporan total data surat masuk, laporan data surat keluar, laporan data bulanan dan tahunan surat masuk, laporan data bulanan dan tahunan surat keluar.

\subsection{Pembahasan}

Penyusunan dan penataan sistem aplikasi surat masuk dan keluar ini didasarkan pada keterkaitan data dengan sistem. Dalam pengembangan sistem digunakan bahasa pemrograman Visual Basic 6.0, MySQL sebagai databasenya dan Crystal Report untuk membuat cetak laporannya. Penggunaan MySQL ini 
sebagai pengganti software spreadsheet yang memiliki beberapa kekurangan seperti dijelaskan oleh Triplet [5].

Aplikasi yang telah dibuat perlu dijalankan untuk melihat apakah program dapat berjalan sesuai yang dibutuhkan atau tidak, karena sifat dari bahasa pemrograman adalah mengikuti apa yang diinginkan oleh operator sementara komputer merupakan sarana untuk menjalankan sistem. Ini merupakan bagian dari proses siklus hidup sistem informasi [7].

Hasil dari perancangan sistem aplikasi surat masuk dan keluar pada PT. Angkasa pura 1 (Persero) kantor Cabang Bandar Udara Internasional Ahmad Yani Semarang yang telah dibuat ternyata dapat dijalankan. Pada sistem ini terdapat dua halaman utama yaitu untuk halaman admin dan user. Pada halaman admin terdapat beberapa menu yaitu menu file yang berisi submenu input data surat masuk, input data surat keluar, input data user, lihat daftar perusahaan, menu laporan yang mempunyai submenu laporan data surat masuk dan surat keluar yang masing-masing terdapat submenu laporan total dan laporan bulanan/ tahunan. Hal yang bisa dilakukan dalam halaman admin yaitu input data surat masuk/ keluar, mengedit dan menghapus data surat masuk/ keluar, pencarian data surat masuk/ keluar dan mencetak laporan data surat masuk/ keluar. Sedangkan hal yang bisa dilakukan pada halaman user yaitu pencarian data surat masuk/ keluar, mencetak laporan data surat masuk/ keluar.

Dalam pembuatan aplikasi sistem surat masuk dan keluar dibuat melalui beberapa tahapan perancangan sistem yang sesuai dengan siklus hidup sistem informasi [7] yaitu tahap awal untuk mengidentifikasi pemasalahan dan pencarian solusi untuk mengatasi permasalahan yang ada yaitu bagaimana merancang sistem aplikasi surat masuk dan keluar untuk mempermudah dalam pengelolaan data surat masuk/ keluar pada PT. Angkasa Pura 1 (Persero) kantor Cabang Bandar Udara Internasional Ahmad Yani Semarang. Setelah tahap awal kemudian tahap desain, dalam tahap ini dilakukukan untuk menentukan ruang lingkup pembuatan aplikasi yang ditangani yang selanjutnya dijabarkan dalam bentuk diagram alir data. Kemudian tahapan perancangan sistem. Tahap perancangan sistem basis data dapat menggambarkan secara umum bentuk sistem yang akan atau telah berlangsung. Tujuan perancangan sistem ini adalah untuk mengendalikan atau memecah tugas ke dalam beberapa model atau sub-sub program kemudian untuk dipakai ke dalam sistem komputerisasi. Setelah tahap perancangan sistem, selanjutnya adalah implementasi sistem.

Aplikasi pengelolaan surat masuk dan keluar ini mempunyai beberapa keunggulan dibandingkan dengan cara pengelolaan surat masuk dan keluar yang dilakukan secara manual. Keunggulan-keunggulan sistem aplikasi ini 
adalah bisa menghasilkan informasi mengenai data surat yang masuk dan keluar dan bisa melakukan proses pencarian data surat masuk dan keluar dalam waktu yang cepat sehingga memudahkan pengguna dalam pencarian data dan pembuatan laporan, di mana hal ini didukung oleh MySQL yang memiliki operator dan fungsi secara penuh yang mendukung perintah Select dan Where dalam perintah (query), keunggulan lainnya adalah program ini bisa menyimpan data dalam bentuk dokumen. Namun, sistem aplikasi ini masih bersifat stand alone, sehingga hanya pada satu komputer yang dapat mengelola sistem, namun hal ini masih memungkinkan untuk dilakukan proses pengembangan untuk sinkronisasi MySQL [5] jika menginginkan untuk beberapa komputer. Kekurangan lain, aplikasi ini belum bisa membuat scanning dokumen secara langsung dari program aplikasi, hal ini sebagai bahan penelitian lebih lanjut.

\section{SIMPULAN}

Berdasarkan hasil dalam pembahasan di atas, maka dapat disimpulkan sebagai berikut:

1. Perancangan sistem aplikasi surat masuk dan keluar yang dibuat pada PT. Angkasa Pura 1 (Persero) kantor Cabang Bandar Udara Internasional Ahmad Yani Semarang menggunakan Visual Basic 6.0, MySQL dan Crystal Report untuk mencetak laporan. Dalam pembuatan perancangan aplikasi ini melalui beberapa tahapan yaitu tahap analisis, tahap desain, tahap perancangan sistem database dan implementasi sistem. MySQL memiliki operator dan fungsi secara penuh yang mendukung perintah Select dan Where dalam perintah (query) dan memiliki antar muka (interface) terhadap berbagai aplikasi dan bahasa pemrograman dengan menggunakan fungsi Application Programming Interface (API).

2. Sistem aplikasi pengelolaan surat masuk dan surat keluar yang diusulkan adalah dengan menggunakan sistem informasi secara komputerisasi maka proses penginputan, pencarian data surat masuk/ surat keluar dan pembuatan laporan dapat dilakukan kapan saja dalam waktu yang cepat karena datadata tersimpan dengan aman dan terstruktur serta tidak terjadi lagi keterlambatan dalam pencarian data. Dengan adanya aplikasi data surat masuk dan surat keluar yang berbasiskan komputerisasi dapat meningkatkan produktifitas kerja khususnya dari segi proses pengelolaan surat masuk/ keluar dan pembuatan laporan akan menjadi cepat dan akurat. 


\section{REFERENSI}

[1] Barthos, Basir., Manajemen Kearsipan Untuk Lembaga Negara, Swasta dan Perguruan Tinggi, Jakarta: PT Bumi Aksara, 1989.

[2] MADCOMS., Panduan Pemrograman dan Referensi Kamus Visual Basic 6.0. Madiun: ANDI, 2006.

[3] Santoso, Harip., Membuat Multiaplikasi mengunakan Visual Basic 6, Jakarta: PT Elex Media Komputindo, 2005.

[4] Sidik, B., MySQL untuk Pengguna, Administrator dan Pengembang Aplikasi Web, Bandung: INFORMATIKA, 2005.

[5] Triplet, T \& Butler, G. The EnzymeTracker: an open-source laboratory information management system for sample tracking. BMC Bioinformatics. 2012

[6] Wursanto. Pembimbing Administrasi dan Surat menyurat, Jogjakarta, 1991.

[7] William, Brian K. Using information technology : a practical introduction to computers \& communications: Complete version. New York: McGraw -Hill 